\title{
A Route from Glycobiology to Congenital Muscular Dystrophy
}

\author{
糖鎖生物学から先天性筋ジストロフィー研究への道 \\ Endo, Tamao \\ Molecular Glycobiology, Tokyo Metropolitan Institute of Gerontology, Itabashi-ku, Tokyo 173-0015, Japan \\ FAX: 81-3-3579-4776, E-mail:endo@tmig.or.jp
}

(Received on April 28, 2010, accepted on May 7, 2010)

Key Words: dystroglycan, O-mannosylation, muscular dystrophy, congenital disorders of glycosylation

\begin{abstract}
Most proteins within living organisms contain glycans. Glycan structures can modulate the biological properties and functions of glycoproteins. The major glycans of glycoproteins can be classified into two groups, $\mathrm{N}$-glycans and $O$-glycans, according to their glycan-peptide linkage regions. This review will give an outline of the $O$-mannosyl glycans; structure, biosynthesis, function, and pathology.
\end{abstract}

\section{A. Introduction}

Proteins produced by eukaryotic cells are frequently post-translationally modified by the addition of glycans. More than half of proteins are known to undergo glycosylation. The glycan moieties of these glycoproteins not only affect their stability and conformation, but also have roles in molecular recognition processes that occur in bacterial and viral infection, cell adhesion in inflammation and metastasis, differentiation, development, and many other events characterized by intercellular communication. The mechanisms underlying the many glycan-mediated recognition processes are not fully understood.

The major glycans of glycoproteins can be classified into two groups according to their glycan-peptide linkage regions. Those that are linked to asparagine (Asn) residues of polypeptides are termed $\mathrm{N}$-glycans, while those that are linked to serine (Ser) or threonine (Thr) residues are called $O$-glycans. In $N$-glycans, the reducing terminal GlcNAc is linked to the amide group of Asn. In $O$-glycans, the reducing terminal GalNAc is attached to the hydroxyl groups of Ser and Thr residues of polypeptides. In addition to the abundant $O$-GalNAc forms, several unique types of protein $O$-glycosylation have been known. For example, $O$-mannosy glycan of dystroglycan (DG) has been shown to be important in muscle and brain development.

Muscular dystrophies are genetic diseases that cause progressive muscle weakness and wasting. The causative
要 約

生体で作られるタンパク質の多くは糖鎖を含んでいる。糖 鎖は糖タンパク質の生物学的な性質や機能に影響を与えるこ とが知られている。糖タンパク質糖鎖は、タンパク質への結 合様式によって $N$ - 型糖鎖と $O$ - 型糖鎖の二つのグループに大 別される。本稿では、 $O$ - マンノース型糖鎖の構造、生合成、 機能、そして病理との関連について概説する。

A. はじめに

有核細胞によって作られるタンパク質の多くは、糖鎖付加 という翻訳後修飾を受けることが知られている。半数以上の タンパク質は糖鎖が付加されている。糖タンパク質の糖鎖は、 タンパク質の安定性や構造に影響を与えるばかりでなく、細 菌やウイルス感染、がん細胞の転移や炎症時の細胞接着、細 胞の分化や増殖など、細胞間コミュニケーションが関わる様々 な過程に抏いて重要な働きをしていると考えられている。し かしながら、糖鎖の関与する認識機構の詳細は、まだ十分に 解明されていない。

糖タンパク質糖鎖は、糖鎖とタンパク質の結合の様式に よって二つのグループに大別される。タンパク質の Asn に結 合する $N$ - 結合型と呼ばれるタイプと、タンパク質の Serや Thr に結合する $O$ - 結合型と呼ばれるタイプがある。 $N$-結合型 糖鎖は GlcNAc がAsnのアミド基に結合しており、O-結合型 糖鎖は GalNAc が Ser や Thr の水酸基に結合している。O-結 合型では最も頻繁に見られる GalNAcに加えて他の糖が結合 していることも知られている。その中の一つ、例えば本稿で 紹介する、ジストログリカン $(\mathrm{DG})$ の研究から展開した $O$ - マ ンノース型糖鎖は、筋や脳の形成に打いて重要な役割を果た している。

筋ジストロフィーは、進行性に筋の変性・壊死を主症状 とする遺伝性疾患である。過去 15 年位の間に数多くの原因遺 
genes of several muscular dystrophies have been identified in the past fifteen years. The best known is the one described by Duchenne that results from mutations in the gene encoding a protein called dystrophin. Another subclass is congenital muscular dystrophies, where muscle weakness is apparent at birth or shortly afterwards. Recent data suggest that aberrant glycosylation of $\alpha$-DG is the primary cause of some forms of congenital muscular dystrophy. This article reviews new insights into the glycobiology of muscular dystrophy.

\section{B. Dystroglycan (DG) and $\boldsymbol{O}$-Mannosyl Glycan}

DG is encoded by a single gene (DAG1) and is cleaved into two proteins, $\alpha$-DG and $\beta$-DG, by posttranslational processing (1). Disruption of this gene in mice results in embryonic lethality. To allow the embryo to develop, chimeric mice generated from targeted embryonic stem cells have been produced. DG-null chimeric mice showed muscular dystrophy, although muscle basement membrane formation was normal (2). The function of DG in specific tissues was examined with the Cre/LoxP system. Targeting the gene in skeletal muscle did not affect muscle basement membrane formation but resulted in a mild dystrophic phenotype (3). Targeting in brain resulted in abnormal cerebral cortical layering resembling human cobblestone lissencephaly, and in abnormal cerebellar granule cell migration (4). Targeting in peripheral nerves caused defects in myelination and nodal architecture (5). DG is also required for polarizing epithelial cells and oocytes in Drosophila (6) and removal of DG causes severe muscular dystrophy in zebrafish embryos (7). These results indicate that DG is essential for normal development.

In skeletal muscle, DG is a component of the dystrophin-glycoprotein complex. $\alpha$-DG is an extracellular peripheral membrane glycoprotein anchored to the cell membrane by binding to a transmembrane glycoprotein, $\beta$-DG. The $\alpha$-DG- $\beta$-DG complex is thought to stabilize the plasma membrane by acting as an axis through which the extracellular matrix is tightly linked to cytoskeleton. This is because $\alpha$-DG strongly binds to laminin in the extracellular matrix, and the cytoplasmic domain of $\beta$-DG interacts with dystrophin, which in turn binds to the actin cytoskeleton (8).

$\alpha$-DG is heavily glycosylated and its sugars have a role in binding to laminin, neurexin and agrin (8). We demonstrated that the major glycans of $\alpha$-DG include $O$-mannosyl glycan: Sia $\alpha 2-3$ Gal $\beta 1-4$ GlcNAc $\beta 1-2 M a n$ (9). Subsequent studies described a series of $O$-mannosyl glycans with heterogeneous mannose-branching (2-substituted and 2,6 -substituted mannoses) and peripheral structures Gal $\beta 1$ 4(Fuc $\alpha 1-3$ )GlcNAc $\beta 1-2 \mathrm{Man}, \mathrm{HSO}_{3}$-3Glc A $\beta 1-3 \mathrm{Gal} \beta 1$ 4GlcNAc $\beta 1$-2Man, Sia $\alpha 2-3$ Gal $\beta 1-4 G l c N A c \beta 1-2$ (Sia $\alpha 2-$ 3Gal $\beta 1-4 G l c N A c \beta 1-6)$ Man]. Recently, a GalNAc $\beta 1$ $3 \mathrm{GlcNAc} \beta 1-4 \mathrm{branch}$ and a phosphodiester-linked modification
伝子が同定された。最も患者数が多いデュシェンヌ型筋ジス トロフィーの原因遺伝子が最初に同定され、スペクトリン様 細胞内タンパク質、ジストロフィンをコードしていることが 明らかになった。他に先天性筋ジストロフィーと呼ばれる一 群があり、出生時あるいは出生直後から筋力低下が顕著であ る。最近の研究により、 $\alpha-\mathrm{DG}$ の糖鎖異常がいくつかの先天 性筋ジストロフィー症の原因であることが判明した。本総説 では、糖鎖研究が筋ジストロフィー研究分野にもたらした新 たな潮流について紹介する。

\section{B. ジストログリカン (DG) とO-マンノース型糖鎖}

DGはDAG1 遺伝子によってコードされているが、翻訳 後 $\alpha$-DG と $\beta$-DG の二つのサブユニットに切断される (1)。DG の遺伝子破壊マウスは、胎生致死である。胎生致死を克服す るために、キメラマウスが作製され解析された。その結果、 筋基底膜の形成は正常であったが、筋ジストロフィー症状を 示した (2)。次に、各組織における DG の役割を明らかにする ために、Cre/LoxP システムによる組織特異的コンディショナ ルノックアウトマウスが作製された。骨格筋特異的にDGの 発現を阻害すると、筋基底膜は影響を受けないが筋ジストロ フィー症状を示した (3)。脳特異的に発現を阻害すると、ヒト 滑脳症に似た大脳皮質層構造の乱れや小脳の顆粒細胞の移動 異常などが観察された (4)。末梢神経特異的に発現を阻害する と、髄鞘や絞輪の形成不全が認められた (5)。一方、ショウジョ ウバエでは卵母細胞や上皮細胞の極性に DG は必要であり (6)、 ゼブラフィッシュ胚では DG がないと筋ジストロフィーが起 こる (7)。いずれの結果も、DG は正常な発生に必須な分子で あることを示している。

DG は、骨格筋に打いてジストロフィン - 糖タンパク質複 合体の一成分として発見された。 $a-D G$ は、細胞膜の外側に存 在し膜貫通の $\beta-\mathrm{DG}$ と結合している。 $\alpha-\mathrm{DG}$ と $\beta-\mathrm{DG}$ の複合 体は、細胞外マトリックスと細胞骨格とを連結させる軸とし て働くことにより筋膜の安定化をもたらしていると考えられ ている。これは、細胞外では $\alpha-D G$ は細胞外マトリックス成

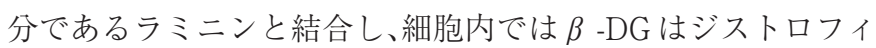
ン、さらにアクチン細胞骨格系と結合していることによる (8)。

$a$-DGは高度に糖鎖修飾を受けており、その糖鎖はラミ ニン、アグリン、ニューレキシンなどとの結合に必要である (8)。我々は、 $\alpha$-DG の主要な糖鎖は $O$ - マンノース型糖鎖と呼 ばれる、Sia $\alpha$ 2-3Gal $\beta$ 1-4GlcNAc $\beta$ 1-2Manであることを明 らかにした (9)。その後複数のグループにより、O-マンノー 又型糖鎖には多様な構造 ( 末端構造や Man からの分岐) があ り、Gal $\beta 1$-4(Fuc $\alpha 1-3$ )GlcNAc $\beta 1-2 \mathrm{Man} 、 \mathrm{HSO}_{3}-3 \mathrm{Glc} A \beta 1$ 3Gal $\beta 1$-4GlcNAc $\beta 1$-2Man, Sia $\alpha$ 2-3Gal $\beta 1-4 \mathrm{GlcNAc} \beta 1$-6(Sia $\alpha 2-$ 
on $O$-mannosyl glycans of $\alpha$-DG were identified (10).

\section{Biosynthesis of $O$-Mannosyl Glycan \\ C-1. Protein $O$-Mannosyltransferase}

The biosynthesis of $O$-mannosyl glycans is started by the addition of Man to Ser/Thr residues of proteins. The enzymes involved in the initiation of protein $O$-mannosylation were identified and characterized in yeast, Saccharomyces cerevisiae. Yeast $O$-mannosylation is initiated in the lumen of the ER by a family of PMTs that catalyze the transfer of Man from Dol-P-Man to Ser/Thr residues of proteins (11). S. cerevisiae has seven PMT homologues (Pmt1p-7p) that share almost identical hydropathy profiles. The hydropathy profiles predict that PMTs are integral membrane proteins with multiple transmembrane domains (11). The PMT family is classified phylogenetically into the PMT1, PMT2, and PMT4 subfamilies. Members of the PMT1 subfamily (Pmt1p and Pmt5p) interact heterophilically with those of the PMT2 subfamily (Pmt2p and Pmt3p), whereas the single member of the PMT4 subfamily (Pmt4p) acts as a homophilic complex (12). Although Pmt1p-4p and Pmt6p have $O$-mannosyltransferase activity by themselves, complex formation is essential for maximal activity (12). It is of interest that $O$-mannosylation is vital in yeast, and its absence affects cell wall structure and rigidity. Additionally, a deficiency in protein $O$-mannosylation in the fungal pathogen Candida albicans leads to defects in multiple cellular functions including expression of virulence (13).

$P M T$ is evolutionarily conserved from prokaryotes, such as Mycobacterium tuberculosis, to eukaryotes, such as yeast, Drosophila, mouse, and human. Human have two homologues of yeast PMT (POMT1 and POMT2) $(14,15)$. The hydropathy profiles of these proteins are almost identical and predict that the integral membrane proteins with multiple transmembrane domains (15-17). We demonstrated that human POMT1 and POMT2 have protein $O$-mannosyltransferase activity, but only when they are co-expressed $(18,19)$. This suggests that POMT1 and POMT2 form a hetero-complex to express enzymatic activity. POMT1 and POMT2 are expressed in all human tissues, but $P O M T 1$ is highly expressed in fetal brain, testis and skeletal muscle, and POMT2 is predominantly expressed in testis $(15,17)$. Disruption of pomtl in mice results in embryonic lethality (20), indicating that protein $O$-mannosylation is essential for normal development.

Drosophila has two PMT orthologs, dPOMT1 and APOMT2, which correspond to human POMT1 and POMT2, respectively $(15,17)$. Two mutants, $r t$ and $t w$, have reduced viability as well as pronounced defects in muscle development and synaptic defects (21). The $r t$ and $t w$ genes were identified as $A P O M T 1$ and $A P O M T 2$, respectively $(14,15,17,22)$. As with human POMT1 and POMT2, co-expression of APOMT1 and
3Gal $\beta$ 1-4GlcNAc $\beta$ 1-2)Man などの構造が報告された。最近、 GalNAc $\beta 1-3 G l c N A c \beta 1-4$ 分岐やリン酸ジエステル構造が $\alpha \mathrm{DG}$ にあることが報告された(10)。

\section{O-マンノース型糖鎖合成に関わる糖転移酵素}

\section{$\mathrm{C}$-1. Protein $O$-mannosyltransferase}

O- マンノース型糖鎖の合成は、タンパク質上の Ser/Thr 残基にMan が付加されることによって開始される。この酵 素 (Protein $O$-mannosyltransferase) は、酵母 Saccharomyces cerevisiae に执いて同定され、その性質が明らかにされた。酵 母の $O$ - マンノース転移は、小胞体の内腔でタンパク質上 のSer/Thr 残基に Dol-P-Man から Man がPMT 群の酵素に よって転移されることで始まる(11)。酵母には同じような疎 水性である 7 つ PMT ホモログ $(\mathrm{Pmtlp} \sim 7 \mathrm{p})$ が知られてい る。疎水性から考えると、PMT は複数回膜貫通のタンパク質 であると予測される。PMT群は進化的に、PMT1、PMT2、 PMT4 の亜群に分類される。PMT1亜群の (Pmtlp と Pmt5p) は PMT2 亜群の (Pmt2 と Pmt3p) との間でへテロ複合体を形 成するが、PMT4 亜群には Pmt4p しかなく、これはホモ複合 体を形成する (12)。Pmtlp〜 Pmt4p と Pmt6p は単独でも酵 素活性をもつが、最大活性を発揮するためには複合体形成が 必須である (12)。タンパク質の $O$ - マンノース化は酵母の生存 に必須であり、O-マンノース化が起こらないと、細胞壁の構 造や堅固さが保たれない。さらに病原性の真菌であるCandida albicans では、病原性に関わることも知られている (13)。

PMT 遺伝子は、Mycobacterium tuberculosis の様な原核 細胞から酵母、ショウジョウバエ、マウス、ヒトまで進化的 に広く保存されている。ヒトには酵母の $P M T$ ホモログとし てPOMT1 とPOMT2 が報告されていた $(14,15)$ 。遺伝子から 予測されるアミノ酸配列は、いずれも複数回膜貫通のタンパ ク質であることを示唆している(15-17)。我々は、POMT1 と POMT2 は $O$ - マンノース転移酵素であるが、酵素活性発現に はPOMT1 とPOMT2 の両方の発現が必要であった $(18,19) 。$ この事実は POMT1-POMT2 のヘテロ複合体形成が必要であ ることを示している。POMT1 とPOMT2 はヒトでは様々な 組織で発現しているが、POMT1 は胎児脳、精巣、骨格筋で強

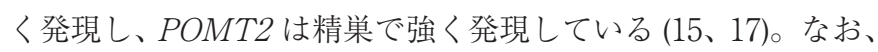
pomt1 の遺伝子破壊マウスは胎生致死となることから (20)、夕 ンパク質の $O$ - マンノシル化は正常な発生に必要な翻訳後修飾 であることが分かる。

ショウジョウバエでもやはり二つのPOMT ホモログ、 dPOMT1 と $d P O M T 2$ が知られている $(15,17) 。 一$ 方、rt と $t w$ という筋形成とシナプス形成異常を示す変異体が知られ ている $(21)$ 。その後が、rt 遺伝子と $t w$ 遺伝子は、それぞれ dPOMT1 と $d P O M T 2$ であることが明らかになった $(14,15,17$, 22)。ヒトの場合と同様にPOMT 活性発現には dPOMT1 と dPOMT2 の両方が必要であることが in vitro 系 (22) および in 
dPOMT2 is required for glycosylation of DG in vitro (22) and in vivo $(21,23)$. Thus, protein $O$-mannosylation is essential for muscle development in both human and flies.

Individual yeast PMTs have different specificities for protein substrates (11), suggesting the presence of a novel recognition mechanism by PMTs. Hutzler et al. reported (24) that Pmt4p mediates $O$-mannosylation of Ser/Thr-rich membrane-bound proteins, whereas Pmt1/Pmt2 complexes act on both soluble and membrane-bound proteins. However, $O$-mannosylation does not depend on the membrane-anchoring sequence, but it is flanked by a Ser/Thr-rich domain facing the endoplasmic reticulum (ER) lumen. The results suggest that yeast $O$-mannosylation does not require a specific sequence of a protein. On the other hand, the only well characterized $O$-mannosylated protein is $\alpha$-DG in mammals. To address the regulation of mammalian $O$-mannosylation, we synthesized a series of peptides and examined whether these peptides worked as acceptors for protein $O$-mannosylation. Based on the in vitro results, we proposed a preferred amino acid sequence [IXPT(P/X)TXPXXXXPTX(T/X)XX] for mammalian $O$-mannosylation. A BLAST search for proteins with this sequence turned up only $\alpha-D G$, suggesting that the primal $O$-mannosylated protein is $\alpha$-DG (25). On the other hand, another group worked with recombinant fragments of $\alpha$-DG and analyzed the $O$-mannosylation by in vivo assays. In contrast to in vitro study, $O$-mannosylation is a more complex regulation and is controlled by peptide regions within and upstream of the $\alpha$-DG mucin domain (26). Further studies are necessary to clarify the regulatory mechanism of protein $O$-mannosylation.

\section{C-2. Protein $O$-Mannose $\beta 1,2-N$-Acetylglucosaminyl- transferase}

In unicellular eukaryotic organisms such yeast, all $O$-mannosyl glycan structures elucidated so far are neutral linear glycans consisting of 1 to 7 mannose residues, oligomannose-type $O$-mannosyl glycans (27). A key difference between yeast and mammalian-type $O$-mannosyl glycans is that those in mammals have the GlcNAc $\beta 1-2$ Man linkage. This linkage is catalyzed by a glycosyltransferase, UDP-GlcNAc: protein $O$-mannose $\beta 1,2-N$-acetylglucosaminyltransferase (POMGnT1). POMGnT1 catalyzes the transfer of GlcNAc from UDP-GlcNAc to $O$-mannosyl glycoproteins (28). We cloned the gene and characterized POMGnT1. The nucleotide sequence of human POMGNT1 indicates that it encodes a 660 amino acid protein and is a type II membrane protein. As described above, mammalian $O$-mannosyl glycan has 2,6-substituted mannose. A gene for such a 6-branching enzyme (GnT-IX, GnT-VB) was shown to be specifically expressed in the brain (29-31). vivo 系 $(21,23)$ で明らかになった。以上の結果、O-マンノース 型糖鎖はヒト (脊椎動物) とハエ (無脊椎動物) を問わず筋形 成において重要であることを示している。

酵母の各 PMTは、それぞれ基質とするタンパク質が異

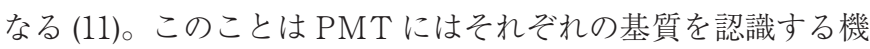
構があると考えられる。そこで Hutzler らは、Pmt4p は膜結 合型のタンパク質の Ser/Thrに富んだ領域をO-マンノシル化 L、Pmt1p/Pmt2p 複合体は可溶性および膜結合性の両方の夕 ンパク質をO-マンノシル化することを明らかにした (24)。し かしながら、O-マンノシル化は膜結合領域の配列に依存する 訳ではなく小胞体の内腔側のSer/Thrに富んだ領域で O- マ ンノース化が起こり、結局 O-マンノシル化は特異的なアミノ 酸配列を要求するものではないことを報告した。一方、哺乳 類では $O$ - マンノシル化されているタンパク質として、 $a-\mathrm{DG}$ が良く知られている。そこで、哺乳類における $O$ - マンノシル 化機構を調べるために、我々は様々な配列を持つペプチドを 合成し、O-マンノシル化の基質になるかどうかin vitro 系で 調べた。その結果、[IXPT $(\mathrm{P} / \mathrm{X}) \mathrm{TXPXXXXPTX}(\mathrm{T} / \mathrm{X}) \mathrm{XX}]$ と いうアミノ酸配列を好んで $O$ - マンノシル化することが分かっ た。BLASTで検索すると、この配列に一致するのは $a-\mathrm{DG}$ だけであったことから、やはり $a-\mathrm{DG}$ は O-マンノシル化され 易いタンパク質であると考えている (25)。一方、他のグルー プは $a-\mathrm{DG}$ の大きな断片を細胞に発現させ、in vivo 系での Oマンノシル化され易さを調べた。その結果、in vitro 系の結果 と異なり、O-マンノシル化はもっと複雑な制御を受けており a-DGのムチン領域の上流部位によって制御を受けているこ とを報告した (26)。O-マンノシル化の制御機構の解明にはさ らに検討が必要であろう。

C-2. Protein $O$-mannose $\beta 1,2-N$-acetylglucosaminyltransferase

酵母のような有核単細胞の $O$ - マンノース型糖鎖は、1〜 7 個の Man が直鎖上につながった構造をしている (27)。この ような酵母でみられるO-マンノース型糖鎖と哺乳類で見られ るO-マンノース型糖鎖の大きな違いは、哺乳類の O- マンノー ス型糖鎖は GlcNAc $\beta$ 1-2Man 構造を持つことである。この構 造を形成する GlcNAc 転移酵素は、POMGnT(Protein O-mannose $\beta 1,2-N$-acetylglucosaminyltransferase) である (28)。我々 は酵素遺伝子のクローニングに成功し POMGnT1 の性質を明 らかにした。POMGnTは UDP-GlcNAc から GlcNAcをタン パク質上の O-マンノース残基に転移する。そのヒト遺伝子は 660 アミノ酸からなるタンパク質をコードしており、II 型の膜 タンパク質である。すでに述べた様に、哺乳類の $O$ - マンノー ス型糖鎖には 2,6 分岐した構造がある。この GlcNAc $\beta 1$ $6 \mathrm{Man}$ 形成に関わる糖転移酵素がクローニングされ (GnT-IX、 GnT-VB)、この遺伝子は脳特異的に発現している (29-31)。 
Table I. Muscular dystrophies possibly caused by abnormal glycosylation.

\begin{tabular}{llllc}
\hline Condition & Gene & Protein function & Gene locus & OMIM \\
\hline $\begin{array}{l}\text { Muscle-eye-brain disease (MEB) } \\
\text { Fukuyama congenital muscular dystrophy }\end{array}$ & POMGNT1 & GlcNActransferase & $1 \mathrm{p} 34-33$ & 253280 \\
(FCMD) & & Putative glycosyltransferase & $9 \mathrm{q} 31$ & 253800 \\
Walker-Warburg syndrome & POMT1 & O-Mannosyltransferase & $9 \mathrm{q} 34.1$ & 236670 \\
(WWS) & POMT2 & & $14 \mathrm{q} 24.3$ & 606612 \\
MDC1C & FKRP & Putative glycosyltransferase & $19 \mathrm{q} 13.3$ & 607155 \\
$\begin{array}{l}\text { Limb-girdle muscular dystrophy 2I } \\
\text { (LGMD2I) }\end{array}$ & & & \\
MDC1D & LARGE & Putative glycosyltransferase & $22 \mathrm{q} 12.3$ & 608840 \\
\hline
\end{tabular}

OMIM = Online Mendelian Inheritance in Man (http://www.ncbi.nih.gov/); MDC, muscular dystrophy, congenital.

\section{Congenital Muscular Dystrophies and Glycosylation Defects}

Aberrant glycosylation of $\alpha$-DG is the primary cause of some forms of congenital muscular dystrophy (Table I). These diseases are called $\alpha$-dystroglycanopathies. Hypoglycosylated $\alpha$-DG has greatly reduced affinities for laminin, neurexin and agrin causing muscle cell degeneration and abnormal brain structure in the diseases listed in Table I.

\section{D-1. Muscle-eye-brain disease (MEB)}

Muscle-eye-brain disease (MEB) is an autosomal recessive disorder characterized by congenital muscular dystrophy, ocular abnormalities and brain malformation (type II or cobblestone lissencephaly). Mutations in the POMGNTI gene were first identified in patients with MEB (28). To confirm that the mutations observed in MEB are responsible for the defects in the synthesis of $O$-mannosyl glycan, we expressed all of the mutant proteins and found that none of them had enzymatic activity $(28,32)$. Together, these findings indicate that MEB is inherited as a loss-of-function of the POMGNT1 gene. If POMGnT1 does not work, no peripheral structure can be formed on $O$-mannosyl glycans. A selective deficiency of glycosylated $\alpha$-DG in MEB patients was found, suggesting that $\alpha-\mathrm{DG}$ is a potential target of POMGnT1 and that hypoglycosylation of $\alpha$-DG may be the pathomechanism of MEB.

\section{D-2. Walker-Warburg Syndrome (WWS)}

Walker-Warburg syndrome (WWS) is another form of autosomal recessive condition characterized by congenital muscular dystrophy, structural brain defects, and eye malformations. Patients with WWS are severely affected from birth and usually die within their first year. At first only mutations in POMT1 were found (33), but none had mutations in POMT2. However, it was speculated that mutations in POMT2 could also lead to disease because POMT1 and POMT2 are both required to achieve protein $O$-mannosyltransferase activity (18). Recent works identified
D. O-マンノース型糖鎖異常と先天性筋ジストロフィー a -DG の糖鎖異常は、ある病型の先天性筋ジストロフィー 症の原因である (表I)。これらの疾患群は、 $a$ - ジストログリ カノパチーと総称される。いずれの疾患も $O$ - マンノース型糖 鎖不全により a -DGとラミニン、ニューレキシン、アグリン などとの結合が低下し、筋膜あるいは基底膜が脆弱となり筋 ジストロフィーや脳奇形を発症すると考えられる。

\section{D-1. Muscle-eye-brain (MEB) 病}

MEB は、筋ジストロフィー、眼疾患、脳奇形 (II 型滑脳症) を特徵とする常染色体劣性遺伝病である。我々は、MEB 患者 において POMGNT1 遺伝子の変異を見いだした (28)。これら のPOMGNT1 遺伝子の変異が $O$ - マンノース型糖鎖の合成不 全をもたらすかどうかを調べたところ、変異を導入した遺伝 子組換え型 POMGnT1 は、すべて酵素活性を失っていた $(28$, 32)。これらの結果は、MEB はPOMGnT1 の機能衣失による $O$ - マンノース型糖鎖不全疾患であることを示している。もし $P O M G n T 1$ が㗢かなければ、上述した $O$ - マンノース型糖鎖の 様々な末端構造は形成されない。実際に、MEB 患者骨格筋に 打ける $\alpha-D G$ の抗糖鎖抗体に対する反応性は消失していた。 このことから、 $a$-DG はPOMGnT1による糖鎖修飾の標的で あり、MEB は $O$ - マンノース型糖鎖不全による疾患であるこ とが明らかになった。

\section{D-2. Walker-Warburg 症候群 (WWS)}

WWS は、筋ジストロフィー、脳奇形、眼疾患を特徵 とする別の常染色体劣性遺伝病である。WWS 患者は出生時 から重篤であり、ほとんど一年以内に死亡してしまう。最初 にWWS の原因遺伝子としてPOMT1 が報告されたが (33)、 POMT2 の報告はなかった。しかしながら、我々が報告した様 に、POMT1 とPOMT2が共存することが O-マンノース転移 酵素として機能するために必要であることから (18)、POMT2 変異による患者がいるのではないかと考えられた。その後 
mutations in the POMT2 gene in this syndrome $(34,35)$, We have demonstrated that the mutations of POMT1 or POMT2 protein found in WWS patients abolished $O$-mannosyltransferase activity $(35,36)$. WWS and MEB are clinically similar disorders, but WWS is a more severe syndrome than MEB. This may be because POMT1 or POMT2 mutations prevent the attachment of any $O$-mannosyl glycans to $\alpha-\mathrm{DG}$ in WWS, while POMGNT1 mutations permit the attachment of a single $O$-mannosyl residue to $\alpha$-DG in MEB.

\section{D-3. Fukuyama-Type Congenital Muscular Dystrophy (FCMD)}

Like MEB and WWS, Fukuyama-type congenital muscular dystrophy (FCMD) is characterized by with central nervous system involvement. Severe mental retardation and epilepsy are characteristic clinical features of FCMD, with brain showing polymicrogyria/pachygyria caused by altered neuronal migration. FCMD is the second most common form of muscular dystrophy in Japan. Kobayashi et al. identified the gene responsible for FCMD, which encodes a protein named fukutin (37). Sequence analysis of fukutin predicts it to be an enzyme that could modify glycoconjugates. Recently, fukutin was reported to be associated with POMGnT1 in the Golgi compartment (38). Transgenic knock-in mouse carrying a retrotransposon insertion in the fukutin gene showed a $30 \%$ reduction of POMGnT1 activity (38), suggesting that fukutin modulates POMGnT1 activity.

\section{D-4. Congenital Muscular Dystrophy Type 1C (MDC1C)} and Limb-Girdle Muscular Dystrophy2I (LGMD2I)

Additionally, congenital muscular dystrophy type $1 \mathrm{C}$ (MDC1C) is caused by mutations in a homologue of fukutin (fukutin-related protein, $F K R P$ ) (39). MDC1C is characterized by a rapidly progressive muscle disease leading to a complete loss of muscle function and lethal respiratory insufficiency during the second decade (40). Mental retardation and cerebellar cysts have been observed in some patients. In contrast, allelic mutations in the FKRP gene cause a milder and more common form of myopathy, named limb-girdle muscular dystrophy2I (LGMD2I), with a variable onset ranging from adolescence to adulthood (41). Although the function of FKRP is unknown, it is suggested that FKRP is involved in the glycosylation of $\alpha-D G$ as a glycosyltransferase or a kind of modulator. Recently, FKRP was reported to be associated with the sarcolemmal dystrophin-glycoprotein complex (42).

\section{D-5. Congenital Muscular Dystrophy Type 1D (MDC1D)}

Finally, the gene large, which is mutated in the myodystrophy (Large ${ }^{\text {myd }}$ ) mouse, encodes a putative glycosyltransferase (43). However, its biochemical activity has not yet been confirmed. The Large ${ }^{\text {myd }}$ mouse showed a progressive muscular dystrophy, ocular defects, and a central nervous system phenotype characterized by abnormal
POMT2 変異の患者が報告された $(34,35)$ 。我々は患者で見 いだされたPOMT1 と POMT2の変異酵素活性を調べた結 果、すべて触媒活性を失っていた $(35,36)$ 。これは、WWS も $\mathrm{MEB}$ と同様 $O$ - マンノース型糖鎖不全疾患であることを示し ている。WWS と MEB は臨床的に似た疾患であるが、一般的 に MEB に比較してWWS の症状の方が重い。POMT1 あるい はPOMT2 変異であるWWS では、 $a-\mathrm{DG}$ の O-マンノース型 糖鎖は全く付かず、POMGNT1 変異である MEB では Man た けは付加されるからであろう。

D-3. 福山型先天性筋ジストロフィー (FCMD)

MEB やWWS と同じように FCMD は、先天性筋ジスト ロフィー、滑脳症と眼奇形を特徵とする。知能発達遅延やて んかん発作もしばしば認められ、神経細胞の移動傷害による 無脳回や厚脳回といった脳奇形を示す。FCMDは日本におい てデュシェンヌ型筋ジストロフィーに次いで多い小児筋ジス トロフィーである。小林らはFCMDの原因遺伝子を特定し、 それはfukutin と名付けたタンパク質をコードしていることを 明らかにした (37)。アミノ酸の配列情報によると、fukutin は 糖鎖修飾に関わる分子であることを予測させる。最近、fukutin はゴルジ体において POMGnT1 と複合体を形成することが 明らかになった (38)。FCMD 患者に最も多くみられる 3’ 非翻 訳領域における $3 \mathrm{~kb}$ のレロトランスポゾン挿入変異を導入 したノックインマウスの POMGnT1 活性は、野生型マウスと 比較して約 30\% 低下していた (38)。この結果から、fukutin は POMGnT1 と相互作用して酵素活性に影響を与えていること が示唆された。

D-4. 先天性筋ジストロフィー1C 型 (MDC1C) と肢帯型筋ジ ストロフィー2I 型 (LGMD2I)

先天性筋ジストロフィー $1 \mathrm{C}$ 型 (MDC1C) は、fukutinの ホモログ (fukutin-related protein、FKRP) の変異による疾患で ある (39)。MDC1C は青年期における重篤な筋衰弱と変性、呼 吸不全症を特徴とする (40)。精神遅延や小脳囊胞が観察される こともある。FKRP 遺伝子の対立変異は、しばしば心筋症を 併発し、青年期から成人期と幅広い発症時期を示す肢帯型筋 ジストロフィー2I 型 (LGMD2I) の原因でもある (41)。FKRP の機能は不明だが、糖転移酵素あるいは糖鎖修飾調節因子と して $a-\mathrm{DG}$ の糖鎖修飾に関与すると考えられている。最近 FKRP は筋細胞膜に存在しジストロフィン - 糖タンパク質複合 体と結合していることが報告された (42)。

D-5. 先天性筋ジストロフィー1D 型 (MDC1D)

最後に、おそらく糖転移酵素をコードしていると思われ る large 遺伝子の変異による筋ジストロフィーモデルマウス $\left(\right.$ Large $\left.{ }^{\mathrm{myd}}\right)$ を紹介する (43)。large 遺伝子産物の生化学的な性 質は明らかになっていない。Large $\mathrm{e}^{\mathrm{myd}}$ マウスは、進行性の筋 ジストロフィー、眼の異常、さらに大脳皮質、小脳、海馬で の神経細胞の遊走異常と基底膜の亀裂を特徴とする中枢神経 
neuronal migration in the cerebral cortex, cerebellum and hippocampus, and disruption of the basal lamina $(8,44)$. Mutations in the LARGE gene cause congenital muscular dystrophy type 1D (MDC1D) with a variable degree of mental retardation and brain abnormalities (45). A study revealed that LARGE can functionally bypass $\alpha$-DG glycosylation defects in many congenital muscular dystrophies, including FCMD, MEB, and WWS (46). Manipulation of $\alpha$-DG glycosylation by LARGE may provide new therapeutic potential for $\alpha$-dystroglycanopathies.

\section{E. Congenital Disorders of Glycosylation (CDG)}

As described, aberrant $O$-mannosylation of $\alpha$-DG causes congenital muscular dystrophy. Lastly, I will introduce defects in general glycosylation pathway and human diseases briefly.

Congenital disorders of glycosylation (CDG) are clinically and genetically heterogeneous group of disorders resulting from abnormal glycosylation. The first patients were described in 1980. Since then, about 40 diseases have been identified (47). Originally CDG was thought to be diseases of protein hypo- $N$-glycosylation. However, disorders are now known to be due to defects not only in $\mathrm{N}$-glycans but also in $O$-glycans, or both on proteins. Further, defects of lipid glycosylation have been reported. Due to the limited space, all diseases cannot be described here. CDG type I is caused by defects of the assembly of lipid-linked oligosaccharides, whereas CDG type II is caused by defects of trimming and elongating of $\mathrm{N}$-glycans involving in nucleotide-transporters. The molecular nature of 14 CDG-I types (CDG-Ia to CDGIn) and 8 CDG-II types (CDG-IIa to CDG-IIh) has been identified.

Recently, abnormalities of intracellular trafficking and organelle $\mathrm{pH}$ also caused defects in glycosylation. Conserved oligomeric Golgi (COG) complex is an eight subunit (COG1-8) peripheral Golgi membrane hetero-oligomeric protein complex and involved in retrograde vesicular Golgi trafficking. In 2004, Wu et al. reported the first patients with a defect in the COG7 subunit by studying of a previously uncharacterized CDG-II (48). Continuously, patients with defects in other subunits $1,8,4$, and 5 were described $(49,50)$. It is well known that the maturation of glycans is occurred through from the ER to Golgi involving in many glycosidases and glycosyltransferases. Deficiencies in retrograde vesicular trafficking Golgi proteins as a cause of glycosylation abnormalities highlighted that the glycosylation process is much more complicated.

Autosomal recessive cutis laxa type II (ARCL II)causing mutations were identified in the ATP6VOA2 gene, encoding the $\alpha 2$ subunit of the vesicular $\mathrm{H}^{+}$-ATPase (V-ATPase) (51). Patients with ARCL II showed a combined
系の異常を起こす $(8,44) 。 L A R G E$ の変異による精神遅延と 脳奇形を伴う先天性筋ジストロフィー $1 \mathrm{D}$ 型 (MDC1D) が報告 された(45)。なお LARGE 強制発現により、FCMD、MEB、 WWS 疾患などの $a-D G$ の糖鎖が回復し、ラミニンとの結合 能も上昇するという (46)。LARGEによる糖鎖付加の充進は、 $a$-ジストログリカノパチーの新たな治療法につながる可能性 がある。

\section{E. 先天性グリコシル化異常症 (CDG)}

前述したように、 $a$-DGのO-マンノシル化の異常は先 天性筋ジストロフィー症を引き起こす。そこで最後に、他の 糖鎖異常疾患として先天性グリコシル化異常症について簡単 に述べる。

先天性グリコシル化異常症 (Congenital disorders of glycosylation：CDG)は、糖鎖の付加異常によって起こる臨床的 にも遺伝子的にも幅広い疾患群である。1980 年に最初の報告 があり、その後現在までに 40 種類以上の CDGのタイプが報 告されている (47)。発見当初は、タンパク質の $N$ - 型糖鎖不全 による疾患と考えられていた。しかしながら、その後の研究 の進展により、 $N$ - 型糖鎖ばかりでなく $O$ - 型糖鎖、あるいは両 方の糖鎖異常の疾患も見つかった。さらに糖脂質の糖鎖不全 も報告された。本稿では全てを紹介することはできないこと を打断りする。二つのタイプに分類され、CDG-I 型と呼ばれ る糖鎖前駆体のオリゴ糖脂質中間体がうまくできないことに よるタイプと、CDG-II 型と呼ばれる糖鎖のプロセッシング過 程や糖又クレオチド輸送体異常などに起因するタイプがある。 これまで 14 種類の CDG-I 型 (CDG-Ia 〜 CDG-In) と、8 種類の CDG-II 型 (CDG-IIa 〜 CDG-IIh) が報告されている。

最近、細胞内輸送過程やオルガネラの $\mathrm{pH}$ なども糖鎖異 常を引き起こすことが明らかになった。Conserved oligomeric Golgi (COG) 複合体は、8つのサブユニット (COG1-8) から構成 され、ゴルジが関与する逆行輸送を行う。2004 年にWu らは、 それまで原因が分からなかったCDG-II 型疾患の解析を進め、 COG7 の異常が原因であることを明らかにした(48)。その後、 次々と他のサブユニット, 1,8,4,5 が原因である $\mathrm{CDG}$ が報告され た $(49,50)$ 。糖鎖は細胞内で小胞体からゴルジを通過する際に、 多くの糖鎖分解酵素や糖転移酵素の働きを受け成熟すること は良く知られている。ゴルジタンパク質の逆行輸送の異常が 糖鎖異常の原因となることは、改めて糖鎖のプロセッシング 過程は予想以上の複雑な制御を受けていることを示している。

常染色体劣性皮膚弛緩症 II 型 (Autosomal recessive cutis laxa type II : ARCL II) の原因遺伝子は、小胞 $\mathrm{H}^{+}$-ATPase (VATPase) の $\alpha 2$ サブユニットをコードするATP6VOA2 遺伝子 である (51)。ARCL II 患者は、 $N$ - 型糖鎖と $O$ - 型糖鎖の両方に 
defect in $N$ - and $O$-glycosylation. The mechanism by which mutations of V-ATPase affect glycosylation remained to be elucidated. Defects in $\mathrm{pH}$ regulation of organelle by proton transport may be considered, because change of $\mathrm{pH}$ in the Golgi apparatus caused redistribution of glycosyltransferases $(52,53)$. A recent study supported above hypothesis because an anion channel (GPHR) modulated Golgi functions including in glycosylation through regulation of acidification (54). Taken together, the CDG studies indicate that correct glycosylation of proteins is essential for normal development.

\section{F. Concluding Remarks}

In summary, $O$-mannosylation is important in muscle and brain development. Interestingly, recent studies suggest $\alpha$-DG $O$-mannosylation is relevant to other diseases. For example, $O$-mannosylation is important for infection of the arenavirus family including the Lassa fever virus and lymphocytic choriomeningitis virus $(55,56)$. Also changes in $\alpha$-DG $O$-mannosylation may play a role in cancer progression $(57,58)$. These results indicate that $\alpha$-DG $O$-mannosylation is an important posttranslational modification.

At present, of the six known $\alpha$-dystroglycanopathy genes, the functions of the protein products are clear only for POMT1, POMT2, and POMGnT1 (Table I). Further, a recent cohort study revealed many patients with $\alpha$-dystroglycanopathy having mutations in any known genes (59). Identification of the other genes and elucidation their function may reveal how $\alpha$-DG glycosylation contributes to muscular dystrophy and how normal glycosylation restores functions of $\alpha-D G$ (Fig. 1). Finally, established mouse models for $\alpha$-dystroglycanopathy will help our understanding
異常がみられる。V-A TPase の変異によって、何故糖鎖異常 が起こるか詳細は不明である。ゴルジ体の $\mathrm{pH}$ の変化は、糖 転移酵素の分布に影響を与えることは良く知られているので (52,53)、プロトン輸送異常によるオルガネラ $\mathrm{pH}$ の制御不全が 原因と考えられる。最近の陰イオンチャネル (GPHR) がオルガ ネラの $\mathrm{pH}$ 調節に関与し糖鎖修飾に影響を与えるという報告は (54)、この仮説を支持する。以上より、CDG 研究は夕ンパク質 の正確な糖鎖修飾の生物学的意義を明示する研究の一つであ る。

F. まとめ

以上まとめると、タンパク質の $O$ - マンノシル化は、筋 や脳の発育形成に必須な翻訳後修飾である。興味深いことに、 最近 $\alpha$-DGのO-マンノシル化は他の疾患にも関係すること が分かった。例えば、ラッサ熱ウイルスやリンパ球脈絡髄膜 炎ウイルスなどのアレナウイルス族の感染に重要である (55、 56)。また、 $a$-DGのO-マンノシル化の変化は、がんの進行 に関わることも報告された $(57,58)$ 。これらの結果も、タンパ ク質の O-マンノシル化は重要な翻訳後修飾であることを示し ている。

現在 6 種の $\alpha$ - ジストログリカノパチーの原因遺伝子の うち、機能が明らかになっているのは、POMT1、POMT2、 POMGnT1 だけである(表I)。さらに,最近の $a$ - ジストログ リカノパチーのコホート研究によると, 原因遺伝子が不明であ る患者が依然として多いという (59)。これら未解明の原因遺伝 子の同定やその機能解明は, $a-D G$ の糖鎖修飾がどのように $a$-ジストログリカノパチーの病理に関わり,$a-D G の$ 機能に 関わるか明らかにすることに貢献するであろう (図 1)。最後に 最近開発された $a$ - ジストログリカノパチーのモデルマウスは
Fig. 1. Proposed $O$-mannosyl glycan processing. POMT1 and POMT2 form a hetero-complex to express protein $O$-mannosyltransferase activity in the ER. After $O$-mannosylated DG is transported to the Golgi, and then POMGnT1 forms a GlcNAc $\beta 1-2$ Man linkage. Then uncharacterized galactosyltransferase (Gal-T) and sialyltransferase (Sia-T) act on $O$-mannosyl glycan. DG having mature $O$-mannosyl glycan is located on the cell surface and binds to extracellular matrix proteins such as laminin. Recent studies suggest that fukutin is associated with POMGnT1, and that Large and FKRP are associated with the DG, although the details are still unclear.

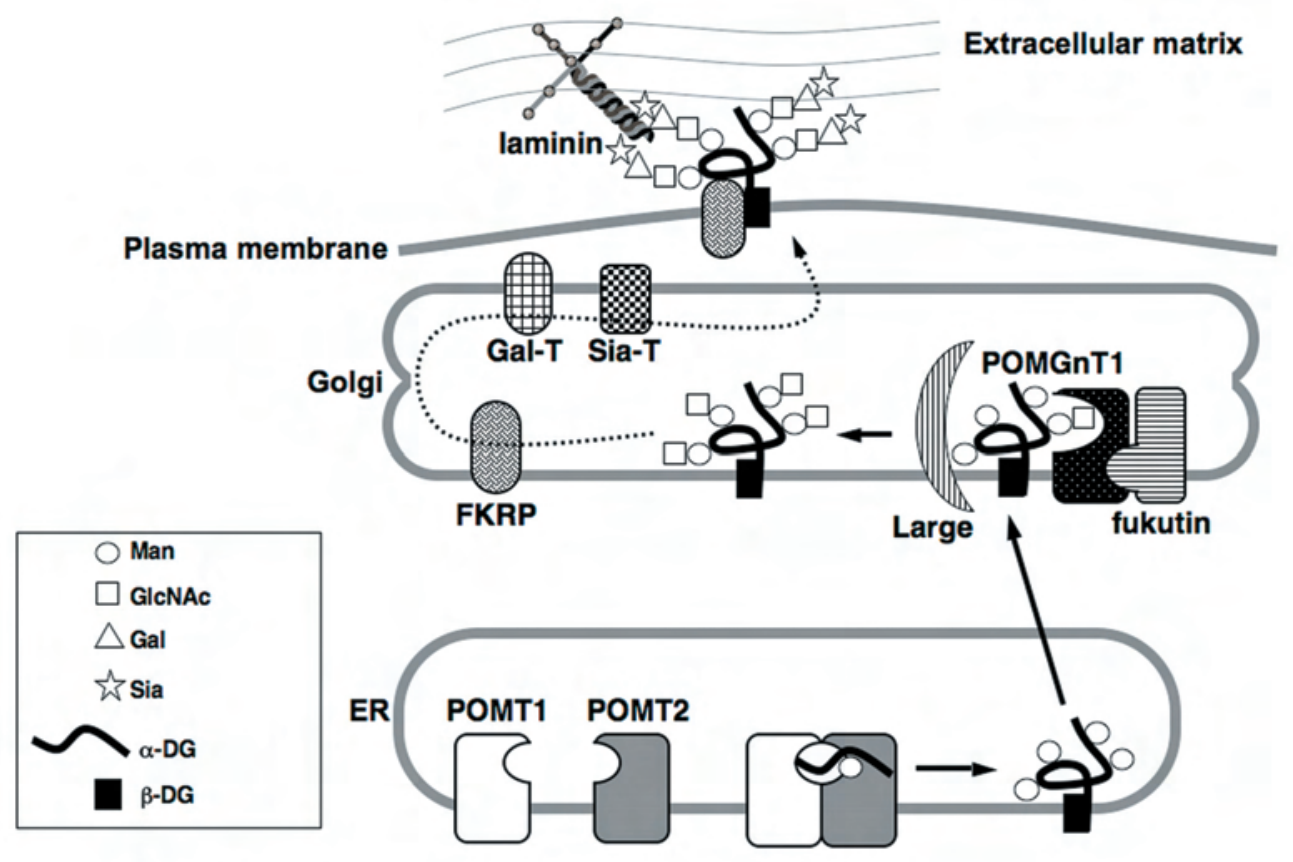

159 (C2010 FCCA (Forum: Carbohydrates Coming of Age) 
between glycosylation and pathophysiology of these diseases and developing new therapies for incomplete glycosylationinduced $\alpha$-dystroglycanopathies (60-62).

\section{Acknowledgement}

I thank Drs. Akemi Suzuki and Makoto Kiso for the suggestions in writing the article to celebrate the 30th Anniversary of Japanese Society of Carbohydrate Research.
(60-62), a - ジストログリカノパチーにおける糖鎖と病態の関 係や，糖鎖不全疾患である $\alpha$-ジストログリカノパチーの新た な治療法の開発に貢献することが期待される。

謝辞

日本糖質学会創立 30 周年の記念号発刊に当り、本稿の執 筆の機会を与えて頂きました鈴木明身博士と木曽真博士に感 謝申し上げます。

\section{References}

1. Barresi, R., and Campbell, K. P. (2006) J. Cell Sci. 119, 199-207.

2. Cote, P. D., Moukhles, H., Lindenbaum, M., and Carbonetto, S. (1999) Nat. Genet. 23, 338-342.

3. Cohn, R. D., Henry, M. D., Michele, D. E., Barresi, R., Saito, F., Moore, S. A., Flanagan, J. D., Skwarchuk, M. W., Robbins, M. E., Mendell, J. R., Williamson, R. A., and Campbell, K. P. (2002) Cell 110, 639-648.

4. Moore, S. A., Saito, F., Chen, J., Michele, D. E., Henry, M. D., Messing, A., Cohn, R. D., Ross-Barta, S. E., Westra, S., Williamson, R. A., Hoshi, T., and Campbell, K. P. (2002) Nature 418, 422-425.

5. Saito, F., Moore, S. A., Barresi, R., Henry, M. D., Messing, A., Ross-Barta, S. E., Cohn, R. D., Williamson, R. A., Sluka, K. A., Sherman, D. L., Brophy, P. J., Schmelzer, J. D., Low, P. A., Wrabetz, L., Feltri, M. L., and Campbell, K. P. (2003) Neuron 38, $747-758$.

6. Deng, W. M., Schneider, M., Frock, R., Castillejo-Lopez, C., Gaman, E. A., Baumgartner, S., and Ruohola-Baker, H. (2003) Development 130, 173-184.

7. Parsons, M. J., Campos, I., Hirst, E. M., and Stemple, D. L. (2002) Development 129, 3505-3512.

8. Michele, D. E., and Campbell, K. P. (2003) J. Biol. Chem. 278, 15457-15460.

9. Chiba, A., Matsumura, K., Yamada, H., Inazu, T., Shimizu, T., Kusunoki, S., Kanazawa, I., Kobata, A., and Endo, T. (1997) J. Biol. Chem. 272, 2156-2162.

10. Yoshida-Moriguchi, T., Yu, L., Stalnaker, S. H., Davis, S., Kunz, S., Madson, M., Oldstone, M. B., Schachter, H., Wells, L., and Campbell, K. P. (2010) Science 327, 88-92.

11. Lehle, L., Strahl, S., and Tanner, W. (2006) Angew. Chem. Int. Ed. Engl. 45, 6802-6818.

12. Girrbach, V., and Strahl, S. (2003) J. Biol. Chem. 278, 12554-12562.

13. Timpel, C., Strahl-Bolsinger, S., Ziegelbauer, K., and Ernst, J. F. (1998) J. Biol. Chem. 273, 20837-20846.

14. Jurado, L. A., Coloma, A., and Cruces, J. (1999) Genomics 58, 171-180.

15. Willer, T., Amselgruber, W., Deutzmann, R., and Strahl, S. (2002) Glycobiology 12, 771-783.

16. Manya, H., Akasaka-Manya, K., Nakajima, A., Kawakita, M., and Endo, T. (2010) J. Biochem. 147, 337-344.

17. Martin-Blanco, E., and Garcia-Bellido, A. (1996) Proc. Natl. Acad. Sci. USA 93, 6048-6052.

18. Manya, H., Chiba, A., Yoshida, A., Wang, X., Chiba, Y., Jigami, Y., Margolis, R. U., and Endo, T. (2004) Proc. Natl. Acad. Sci. USA 101, $500-505$.

19. Akasaka-Manya, K., Manya, H., Nakajima, A., Kawakita, M., and Endo, T. (2006) J. Biol. Chem. 281, 19339-19345.

20. Willer, T., Prados, B., Falcon-Perez, J. M., Renner-Muller, I., Przemeck, G. K., Lommel, M., Coloma, A., Valero, M. C., de Angelis, M. H., Tanner, W., Wolf, E., Strahl, S., and Cruces, J. (2004) Proc. Natl. Acad. Sci. USA 101, 14126-14131.

21. Wairkar, Y. P., Fradkin, L. G., Noordermeer, J. N., and DiAntonio, A. (2008) J. Neurosci. 28, 3781-3789.

22. Ichimiya, T., Manya, H., Ohmae, Y., Yoshida, H., Takahashi, K., Ueda, R., Endo, T., and Nishihara, S. (2004) J. Biol. Chem. 279, 4263842647.

23. Nakamura, N., Stalnaker, S. H., Lyalin, D., Lavrova, O., Wells, L., and Panin, V. M. (2010) Glycobiology 20,381-394.

24. Hutzler, J., Schmid, M., Bernard, T., Henrissat, B., and Strahl, S. (2007) Proc. Natl. Acad. Sci. USA 104, 7827-7832.

25. Manya, H., Suzuki, T., Akasaka-Manya, K., Ishida, H. K., Mizuno, M., Suzuki, Y., Inazu, T., Dohmae, N., and Endo, T. (2007) J. Biol. Chem. 282, 20200-20206.

26. Breloy, I., Schwientek, T., Gries, B., Razawi, H., Macht, M., Albers, C., and Hanisch, F. G. (2008) J. Biol. Chem. 283 , $18832-18840$.

27. Strahl-Bolsinger, S., Gentzsch, M., and Tanner, W. (1999) Biochim. Biophys. Acta 1426, 297-307.

28. Yoshida, A., Kobayashi, K., Manya, H., Taniguchi, K., Kano, H., Mizuno, M., Inazu, T., Mitsuhashi, H., Takahashi, S., Takeuchi, M., Herrmann, R., Straub, V., Talim, B., Voit, T., Topaloglu, H., Toda, T., and Endo, T. (2001) Dev. Cell 1, 717-724

29. Inamori, K., Endo, T., Ide, Y., Fujii, S., Gu, J., Honke, K., and Taniguchi, N. (2003) J. Biol. Chem. 278, $43102-43109$.

30. Kaneko, M., Alvarez-Manilla, G., Kamar, M., Lee, I., Lee, J. K., Troupe, K., Zhang, W., Osawa, M., and Pierce, M. (2003) FEBS. Lett. $\mathbf{5 5 4}, 515-519$

31. Inamori, K., Endo, T., Gu, J., Matsuo, I., Ito, Y., Fujii, S., Iwasaki, H., Narimatsu, H., Miyoshi, E., Honke, K., and Taniguchi, N. (2004) J. Biol. Chem. 279, 2337-2340.

32. Manya, H., Sakai, K., Kobayashi, K., Taniguchi, K., Kawakita, M., Toda, T., and Endo, T. (2003) Biochem. Biophys. Res. Commun. 306, 93-97.

33. Beltran-Valero De Bernabe, D., Currier, S., Steinbrecher, A., Celli, J., Van Beusekom, E., Van Der Zwaag, B., Kayserili, H., Merlini, L., Chitayat, D., Dobyns, W. B., Cormand, B., Lehesjoki, A. E., Cruces, J., Voit, T., Walsh, C. A., Van Bokhoven, H., and Brunner, H. G. (2002) Am. J. Hum. Genet. 71, 1033-1043.

34. van Reeuwijk, J., Janssen, M., van den Elzen, C., Beltran-Valero de Bernabe, D., Sabatelli, P., Merlini, L., Boon, M., Scheffer, H., Brockington, M., Muntoni, F., Huynen, M. A., Verrips, A., Walsh, C. A., Barth, P. G., Brunner, H. G., and van Bokhoven, H. (2005) J. Med. Genet. 42, 907-912.

35. Manya, H., Bouchet, C., Yanagisawa, A., Vuillaumier-Barrot, S., Quijano-Roy, S., Suzuki, Y., Maugenre, S., Richard, P., Inazu, T., Merlini, L., Romero, N. B., Leturcq, F., Bezier, I., Topaloglu, H., Estournet, B., Seta, N., Endo, T., and Guicheney, P. (2008) Neuromuscul. Disord. 18, 
45-51.

36. Akasaka-Manya, K., Manya, H., and Endo, T. (2004) Biochem. Biophys. Res. Commun. 325, 75-79.

37. Kobayashi, K., Nakahori, Y., Miyake, M., Matsumura, K., Kondo-Iida, E., Nomura, Y., Segawa, M., Yoshioka, M., Saito, K., Osawa, M., Hamano, K., Sakakihara, Y., Nonaka, I., Nakagome, Y., Kanazawa, I., Nakamura, Y., Tokunaga, K., and Toda, T. (1998) Nature 394, 388392.

38. Xiong, H., Kobayashi, K., Tachikawa, M., Manya, H., Takeda, S., Chiyonobu, T., Fujikake, N., Wang, F., Nishimoto, A., Morris, G. E., Nagai, Y., Kanagawa, M., Endo, T., and Toda, T. (2006) Biochem. Biophys. Res. Commun. 350, 935-941.

39. Brockington, M., Blake, D. J., Prandini, P., Brown, S. C., Torelli, S., Benson, M. A., Ponting, C. P., Estournet, B., Romero, N. B., Mercuri, E., Voit, T., Sewry, C. A., Guicheney, P., and Muntoni, F. (2001) Am. J. Hum. Genet. 69, 1198-1209.

40. Quijano-Roy, S., Galan, L., Ferreiro, A., Cheliout-Heraut, F., Gray, F., Fardeau, M., Barois, A., Guicheney, P., Romero, N. B., and Estournet, B. (2002) Neuromuscul. Disord. 12, 466-475.

41. Brockington, M., Yuva, Y., Prandini, P., Brown, S. C., Torelli, S., Benson, M. A., Herrmann, R., Anderson, L. V., Bashir, R., Burgunder, J. M., Fallet, S., Romero, N., Fardeau, M., Straub, V., Storey, G., Pollitt, C., Richard, I., Sewry, C. A., Bushby, K., Voit, T., Blake, D. J., and Muntoni, F. (2001) Hum. Mol. Genet. 10, 2851-2859.

42. Beedle, A. M., Nienaber, P. M., and Campbell, K. P. (2007) J. Biol. Chem. 282, 16713-16717.

43. Holzfeind, P. J., Grewal, P. K., Reitsamer, H. A., Kechvar, J., Lassmann, H., Hoeger, H., Hewitt, J. E., and Bittner, R. E. (2002) Hum. Mol. Genet. 11, 2673-2687.

44. Grewal, P. K., Holzfeind, P. J., Bittner, R. E., and Hewitt, J. E. (2001) Nat. Genet. 28, 151-154.

45. Longman, C., Brockington, M., Torelli, S., Jimenez-Mallebrera, C., Kennedy, C., Khalil, N., Feng, L., Saran, R. K., Voit, T., Merlini, L., Sewry, C. A., Brown, S. C., and Muntoni, F. (2003) Hum. Mol. Genet. 12, 2853-2861.

46. Barresi, R., Michele, D. E., Kanagawa, M., Harper, H. A., Dovico, S. A., Satz, J. S., Moore, S. A., Zhang, W., Schachter, H., Dumanski, J. P., Cohn, R. D., Nishino, I., and Campbell, K. P. (2004) Nat. Med. 10, 696-703.

47. Jaeken, J., Hennet, T., Matthijs, G., and Freeze, H. H. (2009) Biochim. Biophys. Acta 1792, 825-826.

48. Wu, X., Steet, R. A., Bohorov, O., Bakker, J., Newell, J., Krieger, M., Spaapen, L., Kornfeld, S., and Freeze, H. H. (2004) Nat. Med. 10, $518-523$.

49. Foulquier, F. (2009) Biochim. Biophys. Acta 1792, 896-902.

50. Paesold-Burda, P., Maag, C., Troxler, H., Foulquier, F., Kleinert, P., Schnabel, S., Baumgartner, M., and Hennet, T. (2009) Hum. Mol. Genet. 18, 4350-4356.

51. Kornak, U., Reynders, E., Dimopoulou, A., van Reeuwijk, J., Fischer, B., Rajab, A., Budde, B., Nurnberg, P., Foulquier, F., Lefeber, D., Urban, Z., Gruenewald, S., Annaert, W., Brunner, H. G., van Bokhoven, H., Wevers, R., Morava, E., Matthijs, G., Van Maldergem, L., and Mundlos, S. (2008) Nat. Genet. 40, 32-34.

52. Rivinoja, A., Hassinen, A., Kokkonen, N., Kauppila, A., and Kellokumpu, S. (2009) J. Cell. Physiol. $220,144-154$.

53. Axelsson, M. A., Karlsson, N. G., Steel, D. M., Ouwendijk, J., Nilsson, T., and Hansson, G. C. (2001) Glycobiology 11, $633-644$.

54. Maeda, Y., Ide, T., Koike, M., Uchiyama, Y., and Kinoshita, T. (2008) Nat. Cell Biol. 10, 1135-1145.

55. Imperiali, M., Thoma, C., Pavoni, E., Brancaccio, A., Callewaert, N., and Oxenius, A. (2005) J. Virol. 79, 14297-14308.

56. Kunz, S., Rojek, J. M., Kanagawa, M., Spiropoulou, C. F., Barresi, R., Campbell, K. P., and Oldstone, M. B. (2005) J. Virol. 79, 1428214296.

57. Bao, X., Kobayashi, M., Hatakeyama, S., Angata, K., Gullberg, D., Nakayama, J., Fukuda, M. N., and Fukuda, M. (2009) Proc. Natl. Acad. Sci. USA 106, 12109-12114.

58. de Bernabe, D. B., Inamori, K., Yoshida-Moriguchi, T., Weydert, C. J., Harper, H. A., Willer, T., Henry, M. D., and Campbell, K. P. (2009) J. Biol. Chem. 284, 11279-11284.

59. Godfrey, C., Clement, E., Mein, R., Brockington, M., Smith, J., Talim, B., Straub, V., Robb, S., Quinlivan, R., Feng, L., Jimenez-Mallebrera, C., Mercuri, E., Manzur, A. Y., Kinali, M., Torelli, S., Brown, S. C., Sewry, C. A., Bushby, K., Topaloglu, H., North, K., Abbs, S., and Muntoni, F. (2007) Brain 130, 2725-2735.

60. Liu, J., Ball, S. L., Yang, Y., Mei, P., Zhang, L., Shi, H., Kaminski, H. J., Lemmon, V. P., and Hu, H. (2006) Mech. Dev. 123, 228-240.

61. Kanagawa, M., Nishimoto, A., Chiyonobu, T., Takeda, S., Miyagoe-Suzuki, Y., Wang, F., Fujikake, N., Taniguchi, M., Lu, Z., Tachikawa, M., Nagai, Y., Tashiro, F., Miyazaki, J., Tajima, Y., Takeda, S., Endo, T., Kobayashi, K., Campbell, K. P., and Toda, T. (2009) Hum. Mol. Genet. 18, 621-631.

62. Miyagoe-Suzuki, Y., Masubuchi, N., Miyamoto, K., Wada, M. R., Yuasa, S., Saito, F., Matsumura, K., Kanesaki, H., Kudo, A., Manya, H., Endo, T., and Takeda, S. (2009) Mech.Dev. 126, 107-116.

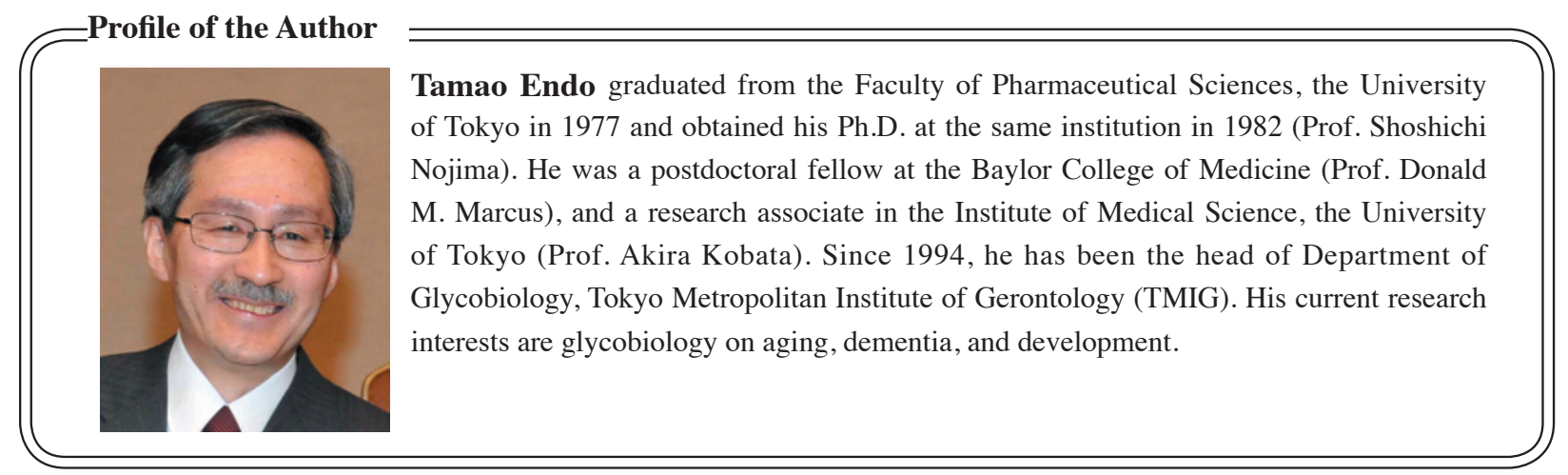

